\title{
Vapaan sivistystyön visiosta
}

\author{
Seppo Niemelä
}

\author{
Yksi mahdollisuus kuvata vapaan sivistystyön \\ omaleimaisuus ja identiteettikin on Tanskan malli, missä \\ vapaalla sivistystyöllä on muusta aikuiskasvatuksesta \\ poikkeava ihmiskuva, yhteisökuva ja pedagogiikka. On \\ tosin muistettava, että vapaalle sivistystyölle ominainen \\ pedagogiikka on kohteena myös tavallisessa \\ aikuiskasvatuksessa, esimerkiksi yhteistoiminnallisen \\ oppimisen tai tiimioppimisen nimillä. Ehdotan silti, että \\ sivistystyön erityistä pedagogiikkaa pidetään huolella \\ silmällä uuden identiteetin rakennustyössä, kirjoittaa \\ Seppo Niemelä.
}

1 Vapaan sivistystyön aseman ja arvostuksen käänne ajoittuu kolmen neljän vuoden takaiseen aikaan. Vuosisadan viimeinen vuosi oli jo riemuvuosi, jonka aikana vapaa sivistystyö teki läpimurron niin kotimaiseksi kuin eurooppalaiseksikin kehittämiskohteeksi. Valtakunnallinen käänne ei vielä ole tavoittanut koko yhteiskuntaa, esimerkiksi vapaan sivistystyön kannalta niin tärkeätä kunnallishallintoa. Silti tie uudelle tulemiselle on tänään avoin.

Vapaan sivistystyön edelleen merkittävä volyymi perustuu siihen pitkäjänteiseen työhön, jota myös Suomessa tehtiin yli sadan vuoden ajan aina 1970-luvulle saakka. Vielä vuoden 1970 aikuiskoulutuskomitea paalutti sen aseman asianmukaisesti, mikä osaltaan tuki määrärahakehitystä pitkälle 80-luvulle.

Kun Olavi Alkio yritti 70-luvun puolivälissä valtioneuvoston periaatepäätöstä alan kehittämiseksi, hanke ei enää onnistunut. Merkki ymmärrettiin opetushallinnossa. Alan kehittäminen käy- tännössä jäädytettiin. Vapaa sivistystyö joutui vapaan pudotuksen tilaan. Oppilaitokset saivat selvitä, miten kukin taisi. Taholla jos toisellakin valmistauduttiin laskemaan koko toimiala täysin palvelleena hautaan. Osoittaa alan elinvoimaa, että se näissäkin oloissa on selviytynyt sittenkin hyvin näihin päiviin.

Alasajon yksi merkki oli Tampereen yliopiston tutkimuksen ja opetuksen kannalta kohtalokas päätös luopua alan ainoasta professuurista. Viran viimeinen haltija kirjoitti vielä 1992, että vuosikymmenen loppuun mennessä tuskin on perusteita sille, että vapaa sivistystyön eroaa muusta aikuiskoulutuksen järjestelmästä. Ennuste näytti toteutuvan, kun ns. Nummisen komitea ehdotti 1996, että vapaa sivistystyön jää ainoana merkittävänä opetushallinnon toimialana vaille omaa lainsäädäntöä.

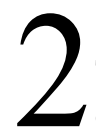
Käänne, joka aiemmin oli jo tapahtunut Tanskassa ja vähän myöhemmin Ruotsissa, oli kuitenkin saavuttamassa Suomen. Kun 
vapaa sivistystyö oli jo vaipumassa uuden aikuiskoulutusjärjestelmän aukkojen paikkaajaksi, sillä nähtiin uudestaan oma itsenäinen roolinsa ja tehtävänsä. Tämä tärkeä ilmaus Suomessa oli koulutuslainsäädännön uusimista käsitelleen parlamentaarisen työryhmän päätös siitä, että vapaa sivistystyö saa oman lakinsa. Sen jälkeinen kehitys on ollut ripeä.

Uuden tulemisen merkkejä on paljon. Opetusministeriön aikuiskoulutuksen päällikkö Marita Savola sanoi haastattelussaan Kansanopisto-lehdessä, että hänen henkilökohtaiseen aikuiskoulutuspoliittiseen visioonsa kuuluu vapaan sivistystyön "eräänlainen uusi tuleminen". Opetusministeriö on toistuvasti osoittanut, ettei tämä ollut vain löysää puhetta. Saamme kiittää opetusministeri Olli-Pekka Heinosta monista alan kannalta keskeisistä kehittämistoimista. Opetusministeri Maija Rask on osoittautunut vapaan sivistystyön ymmärtäjäksi ja kannattajaksi.

Elinikäisen oppimisen komitea loi vuonna 1997 pohjan nyt toteutettavalle aikuiskoulutuksen kehittämiselle. Komitea päätti tietoisesti, että vapaa sivistystyö on ainakin kahdelta tärkeältä osalta yksi elinikäisen oppimisen toteuttaja. Se voi tukea uudelleen tärkeään arvoon noussutta persoonallisuuden kehitystä ja vahvistaa tätä kautta oppimisen perustaa. Osana kaiken oppimisen arvonnousua tuli myös vapaaehtoisesta kansalaistoiminnasta tärkeä oppimisympäristö. Komitean mukaisilla elinikäisen oppimisen tavoitteilla joukossa mm. persoonallisuuden kehitys, demokraattiset arvot, yhteisöjen toimivuus ja sosiaalinen koheesio - on suuri yhteensopivuus vapaan sivistystyön kanssa.

Vuosisadan viimeinen vuosi näki kolme vapaan sivistystyön tulevaisuudelle ratkaisevaa tointa. Niistä tärkein on Lipposen toisen hallituksen päätös ottaa vapaa sivistystyö erityiseksi kehittämiskohteeksi. Linjaus näkyy opetusministeriön uudessa koulutuksen ja tutkimuksen kehittämissuunnitelmassa. Tätä ennakoi opetusministeriön päätös mahdollistaa vapaan sivistystyön VSOP -nimen saanut kehittämisohjelma. Ja omalla laillaan tärkeä oli sekin, että suomalaisen vapaa sivistystyö sai osana Suomen EU-puheenjohtajakauden toimia esitellä ajatteluaan ja rikasta toi- mintansa kenttää eurooppalaisille kollegoille lyhyesti sanoen häikäisevän menestyksekkäästi. Me jätimme tässäkin suhteessa pysyvän puumerkin eurooppalaisen ajattelun kehitykseen.

Uutta tulemista tukee nyt myös kansainvälinen kehitys. Sen taustalla on keskeiseksi tietoyhteiskunnan koulutuspoliittiseksi käynnistäjäksi noussut OECD. Se tajusi ensimmäisenä koulutuksen ja aikuiskasvatuksen strategisen merkityksen ja lanseerasi elinikäisen oppimisen ajatuksen. Sanotaan, että järjestö pelästyi itsekin sitä, miten helposti sen silloin kovin teollisuuspainotteinen sanoma läpäisi koko läntisen maailman. OECD alkoi ensimmäisenä puhua laajemman näkemyksen puolesta.

Voisimme tiivistää OECD:n uudemman näkemyksen seuraavasti. Elleivät ihmiset ole aloitekykyisiä persoonallisuuksia, elleivät lähiyhteisöt toimi, ellei toiminta niin lähiyhteisöissä kuin laajemminkin perustu demokratiaan ja yhteisöjen sosiaalinen koheesio kestä, turha on edes haaveilla taloudesta, joka on "innovatiivinen, produktiivinen ja kasvava”. Tämä sanoma on nyt vilkkaan keskustelun kohteena kaikkialla teollisessa maailmassa. Se sisältää vapaan sivistystyön ajankohtaisen haasteen. Ja tässä suomalaiset ovat Turun kokouksen jälkeen, elinikäisen oppimiseen laajan tulkinnan ja VSOP -ohjelmansa vuoksi kehityksen eturintamassa ja myös kansainvälisen kiinnostuksen kohteita.

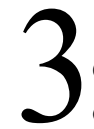

Nähdäkseni ei ole enää kysymystäkään siitä, etteikö vapaa sivistystyö olisi nousussa. Se on taas kerran murrosajan välttämättömyys. 
Nyt murroksena on myöhäisteollisen, kaikki aiemmat rajat ylittävän tieto- ja tuotantoverkostojen ja tiedolle perustuvan yhteiskunnan synty taustanaan globaalit avoimet kiristyvän kilpailun markkinat.

Tässä maailmassa on kolme keskeistä selviytymiskeinoa: oppimisen avulla syntyvä uusi osaaminen, yhteistyöstä syntyvä toimintojen ja talouden verkottuminen sekä kaiken pohjana ihmisten minuuden ja lähiyhteisöjen eheys. Vapaalla sivistystyöllä on annettavansa näihin kaikkiin. Se luo ja vahvistaa oppimisen perustaa ja henkistä pääomaa, se kehittää jo pedagogiikkansa perusteiden mukaisesti yhteistyötä ja sosiaalista pääomaa ja sen erityinen tehtävä on vanhastaan ollut minuuden rakentaminen ja lähiyhteisöjen toiminta.

Kiljavan opiston rehtori Pertti Rantanen nostaa kuitenkin Aikuiskasvatus-lehdessä 4/1999 esiin tärkeän kysymyksen. Nouseeko vapaa sivistystyö alan perinteisten oppilaitosten kautta? Vai murtaako se itselleen uudet polut ja tulee "työttömien yhdistyksissä, rocklyriikassa, kyläprojekteissa, tietoverkkokeskusteluissa, erilaisten asioiden ympärille syntyvissä spontaaneissa ryhmissä jne"? Ennustan, että tulemme keskustelemaan paljon tästä kysymyksestä.

Oma kantani on, että vapaan sivistystyön nykypohja - lähes neljänsadan oppilaitoksen maankattava verkko, yli 2000 ammattitaitoista vakinaista ihmistä, kymmenet tuhannet tuntiopettajat, laajat yhteydet kansalaisyhteiskuntaan ja vakiintunut yli 700000000 markan rahoitus valtion budjetista - on arvokas vapaan sivistystyön uuden tulemisen pohja. Rantanen asettaa mielestään houkuttelevalta tuntuvan tavoitteen, "yhdistelmän, jossa olemassa oleva oppilaitoskenttä henkilöstöineen ja ammattitaitoinen voisi verkostua uusien ja yllättävien porukoiden, tekemisen tapojen ja yhteisöllisen toiminnan ulottuvuuksien kanssa”. Ratkaisevaa on, miten hyvin vapaa sivistystyö tunnistaa uudet työnsä tarpeet ja miten se menee uusia tarpeita vastaan. Tähän VSOP -ohjelma antaa puitteet.
4 Arja Mäkeläinen on jo pitkään herätellyt kysymystä erityisen vapaan sivistystyön strategian tarpeesta. Opetusministeriö hyväksyy kyllä sen, että vapaa sivistystyö on vapaata, mutta silti se tarvitsisi jonkinlaisen hahmon oman päätöksentekonsa pohjaksi. Strategia tuntuu ainakin toistaiseksi kuitenkin liian vaativalta. Siksi oikeampi nimitys on visio, konkreettisuuteen pyrkivä kuva lähivuosien tavoitteesta.

Vision tarve on ilmeinen. Sen tulisi paikantaa vapaan sivistystyön asema koulutuksen kokonaisuudessa ja suhteessa uusiin haasteisiin. Sen tulisi antaa kuva suunnasta, johon vapaata sivistystyötä tulisi kehittää hallituksen periaatelinjausta toteutettaessa. Visio suuntaa myös VSOP -hankkeen mukaisia opintoja. Visio voinee palvella taustana sille, kun alan oppilaitokset tekevät omia visioitaan ja strategioitaan. Ja kun vapaan sivistystyön arviointi uuden lainkin mukaan säännöllistyy, visio luo pohjan sille, mitä toiminnassa arvioidaan. Ja lopuksi visio on päätöksentekijälle paperi, jonka tulisi auttaa arvioimaan vapaan sivistystyön julkinen rahoitus.

Kyseessä on siis tärkeä paperi. Täyttääkö nyt tehty luonnos näin vaativat tarpeet, on kysymys, jonka jätän kernaasti arvioitavaksi. Vapaa sivistystyö saattaa hyvinkin olla sellaisen prosessin alussa, jossa nyt on mahdollista nähdä vain tulevan ääriviivat ja jossa myös vision täytyy lähivuosina jatkuvasti täsmentyä. Tällä visiolla on sekin ongelma, että vision - ollakseen vaikuttava - täytyy olla jaettu visio, jonka mahdollisimman moni voi omista perusteistaan käsin hyväksyä. Vaikka me pyrimme herättämään laajan keskustelun ja saimme joukon hyvin kiinnostavia näkemyksiä, tämä visio on tehty liian kiireellä. Mutta nyt keskustelulla on lähtökohta.

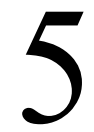

Visiotyössä ei voi välttää kysymystä siitä, mitä vapaa sivistystyö on. Yksi ja toistaiseksi käypänenkin tapa on sanoa, että se tarkoittaa vapaan sivistystyön lain mukaista, kansalais- ja työväenopistoissa, kansanopistoissa, opintokeskuksissa, kesäyliopistoissa ja tässä visiossa myös neuvonnassa harjoitettavaa toimintaa.

Tämän perusteen pitkäaikaisesta käytöstä on kui- 
tenkin syytä varottaa. Vapaa sivistystyö on kyettävä kuvaamaan ja perustelemaan vahvoin sisällöllisin syin, hyvin perusteltuna koulutuksen kokonaisuuden osana, myös todennäköisiä uusia lakikeskusteluja varten. Itse näen, että voimassa oleva laki yhdessä VSOP -ohjelman kanssa on ennen muuta vapaalle sivistystyölle annettu mahdollisuus kehittää uudelleen vahva itsenäisen olemassaolon perusta ja sitä tukeva omaleimainen vahva toimintakulttuuri.

Usein vapaata sivistystyötä käytetään synonyymina vapaatavoitteisen tai nonformaalin koulutuksen kanssa. Tällöin muu aikuiskasvatus olisi formaalia, tutkintotavoitteista. Perusteella on se etu, että se tuo esiin vapaaseen sivistystyöhön aina kuuluneen oppimisen itseisarvoisuuden ilman erityistä tutkinnon ja todistuksen tavoitetta.

Vapaan sivistystyön samaistaminen vapaatavoitteisiin opintoihin on silti ongelmallista. Tärkeä syy on tietysti se, ettei teoria pidä yhtä todellisuuden kanssa. Suuri osa vapaan sivistystyön nykyvolyymistä käytetään sekä yleissivistävään että ammatilliseen tutkintotavoitteiseen opetukseen. Myös elinikäisen oppimisen ajattelusta tuleva 'opitun tunnustamisen' paine hämärtää jakoa vapaa- ja tutkintotavoitteisiin opintoihin. Niinpä toiminta voi olla täysipainoista vapaata sivistystyötä siitä riippumatta, onko sen tuloksena tutkinto, muu opitun tunnustaminen tai vain osallistumistodistus.

On kuitenkin mielestäni tärkeä periaate, että vapaan sivistystyön kaikkia opintoja tulee voida harjoittaa myös nonformaalisti, ilman tutkintotavoitetta. Perimmiltään on oppijan oma asia päättää, kummalla tavalla hän opintojaan harjoittaa. Vapaan sivistystyön tekijän ammattitaitoa on kyetä motivoimaan opinnot myös silloin, kun mahdollisuus todistuksella "kiristämiseen" puuttuu.

Yksi mahdollisuus kuvata vapaan sivistystyön omaleimaisuus ja identiteettikin olisi Tanskan malli. Sen mukaan vapaalla sivistystyöllä on muusta aikuiskasvatuksesta poikkeava ihmiskuva, yhteisökuva ja pedagogiikka. Me olemme kuitenkin viime vuosikymmeninä keskustelleet vapaasta sivistystyöstä aivan liian vähän ja käytössämme on liian vähän vapaa sivistystyötä koskevaa uutta tutkimusta, jotta mikään tästä lähtökohdasta tehtävä kuvaus voisi olla ainakaan jaetun vision pohja.

Silti ehdottaisin, että esimerkiksi vapaan sivistystyön erityistä pedagogiikkaa pidettäisiin huolellisesti silmällä uuden identiteetin rakennustyössä. Se saattaisi olla monin tavoin hedelmällistä. Tosin tämän perusteen haittana on - paitsi se, ettei teoria tässäkään vastaa koko todellisuutta - se, niin Tanskassa kuin Suomessakin havaittu seikka, että vapaalle sivistystyölle ominainen pedagogiikka on vilkkaan kiinnostuksen kohteena myös tavallisessa aikuiskasvatuksessa, esimerkiksi yhteistoiminnallisen oppimisen tai tiimioppimisen nimillä.

Niinpä vapaan sivistystyön määrittelyssä jää käteen itse sivistys, kuvattuna tässä samoin kuin vapaan sivistystyön laissa. Tällöin sivistyksellä ja sitä tukevalla vapaalla sivistystyöllä on kaksi erikseen tai yhdessä toimivaa kiinnekohtaa, persoonallisuuden monipuolisuus ja yhteisöllisyys tai laajemmin kansalaisyhteiskunta.

Persoonallisuus monipuolistuu, kun ihminen kehittää esiin itsessään piileviä ituja ja mahdollisuuksia. Tämä voi tapahtua joko itseisarvoisesti omien tavoitteidensa mukaisesti itseään kehittämällä tai annettujen tavoitteiden mukaan ammatillisesti. Näidenkin välinen raja on tosin yhä hämärämpi esimerkiksi modernin työelämän korostamien laaja-alaisten persoonallisten kvalifikaatioiden - sellaisten kuin joustavuus, innovatiivisuus, empaattiset kyvyt, avoimuus ja itsenäisyys - vuoksi.

Mutta tärkeää on, että vapaa sivistystyö voi ja saa pitää persoonallisuuden monipuolisuutta arvokkaana silloinkin, kun sille ei ole osoitettavissa suoria ammatillisia kytkentöjä. Tiedollisen ohella tehtävä avautuu esteettiseen, eettiseen ja sosiaaliseen suuntaan, voi käsitellä elämän- ja maailmankatsomusta ja ottaa pään taitojen ohella huomioon käden taidot ja ilmaisun.

Toinen kiinnekohta on yhteisöllisyys; vapaa si- 
vistystyö on kansalaisyhteiskunnan koulu tehtäväkenttänään lähiyhteisöt perheestä alkaen, tuhannet ja taas tuhannet paikalliset yhdistykset sekä kansalaisjärjestöt, joiden toimintakenttä ulottuu eurooppalaisiin ja globaaleihin mittoihin. Jos persoonallisuuden kehitys lisää henkistä pääomaa, yhteisöllinen toiminta lisää sosiaalista pääomaa. Tämän merkitystä tähdensi myös Tasavallan Presidentti Uuden Vuoden puheessaan. Kansalaisyhteiskunta on vapaa sivistystyön omin toimintakenttä, jos kohta se saa myös tällä alueella varautua kiristyvään kilpailuun.

Kytkiessään itsensä persoonallisuuden monipuolisuuteen ja yhteisöllisyyteen, vapaa sivistystyö liittää itsensä kahteen nyky-yhteiskunnan ydinkysymykseen ja samalla kipupisteeseen, joita ongelmina kuvaavat sellaiset sanat kuin minuuden hajoaminen, elämänilon ja motivaation katoaminen, uupuminen ja loppuun palaminen, tarkoituksettomuuden ja tyhjyyden kokemukset, pitkäaikaistyöttömyys, keinotekoiset vahingolliset elämykset esimerkkinään huumeet sekä toisaalta yksinäisyys, itsekkyys, piittaamattomuus ja yhteisvastuun puute.

Visioluonnos ehdottaa, että sivistystehtävän käytännön toteutuksessa voisimme hyväksyä vapaata sivistystyötä yhdistäväksi siteeksi toimintakulttuurin, jossa toteutuu itsenäinen tehtävänhaku, toiminnan vapaus, osallistumisen vapaaehtoisuus, osanottajien mahdollisuus ohjata toimintaa, mahdollisuus arvoperustaisuuteen, tasa-arvo keskeisenä tavoitteena ja toiminta kansalaisyhteiskunnan kouluna. Nämä ovat yksi yhteenveto vapaan sivistystyön pohjoismaisesta perinteestä ja sisältävät myös lain velvoitteen edistää tasa-arvoa, kansanvaltaisuutta ja moniarvoisuutta. Tällaisena vapaa sivistystyö on mielestäni selvästi itsenäinen, muusta aikuiskoulutuksesta poikkeava kokonaisuutensa ja sellaisena myös jatkossa oman lakinsa väärti.

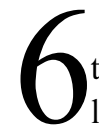
VSY:n laajennettu työvaliokunta kokoontui syksyllä Yleisradioon pohtimaan visio luonnosta ja tutustui samalla YLE:n vastaavaan työhön. Jyrki Ijäs ehdotti silloin, että myös vapaan sivistystyön visiossa on käsiteltävä toimialan yleisösuhdetta. Törmäämme tässä heti tiedon ja tutkimuksen puutteeseen. Mutta vihje johti siihen, että vapaan sivistystyön kannalta suomalaiset jaettiin kolmeen luokkaan: sivistyssuuntautuneisiin eli niihin, joilla on tottumus käyttää vapaan sivistystyön palveluita, sivistysvalmiisiin eli niihin, joilla on valmius hyvän tarjonnan sattuessa käyttää palveluita ja sivistyspenseisiin, jotka eivät osallistu toimintaan. Tämäkin karkea jako paljastaa joitakin hypoteesinomaisia seikkoja.

On todennäköistä, että vapaa sivistystyö toimii jo nyt sivistyseroja tasaavasti. Korkeimmin koulutetut eivät välttämättä osallistu siihen kovinkaan aktiivisesti. Vastaavasti vapaan sivistystyön moniin toimintoihin osallistuu myös hyvinkin vähäisen pohjakoulutuksen saaneita. Silti sekä sivistyssuuntautuneiden että -valmiiden yhteismäärä jää alle miljoonan suomalaisen. Ainakin kolme neljästä suomalaisesta on sen vaikutuspiirin ulkopuolella.

Epäkohta vain pahenee siksi, että myös vapaa sivistystyö joutuu nykyisten rahoitusperiaatteidensa vuoksi entistä enemmän suuntaamaan toimintaansa maksukykyisen kysynnän mukaan. Tämä johtaa tarjonnan lisäämiseen niille, joilla on jo tottumus tai valmius kehittää itseään. Vapaa sivistystyö ei pysty panostamaan riittävästi lain sille antamaan tavoitteeseen, tasa-arvon toteuttamiseen suomalaisessa yhteiskunnassa.

Voidaan odottaa, että jatkossa jotkin vapaan sivistystyön sisäiset painopisteet muuttuvat. Esimerkiksi nuorisoikäluokkien pieneneminen yhdessä koulutuspaikkojen kasvun kanssa siirtänee toimintaa nykyistä vanhempiin ja myös ikääntyviin ihmisiin. Silti tähänastisessa keskustelussa ei ole ehdotettu, että joistakin oleellisista nykyisistä toiminnoista luovuttaisiin. Jos uusia ihmisryhmiä halutaan tavoittaa, ainoaksi mahdollisuudeksi jää tarjonnan lisääminen. Ja juuri tätä visio ehdottaa.

\footnotetext{
7 Vapaan sivistystyön vision sanoma suomalaiselle yhteiskunnalle on seuraava: Päätöksentekijöillä on vapaan sivistystyön lain piiriin kootuissa toiminnoissa käytössään keino, jonka avulla on mahdollista lievittää monia myöhäisteollisen yhteiskunnan kipeitä ongelmia ja
} 
saavuttaa keskeisiä tasa-arvoa, kansanvaltaa ja moniarvoisuutta koskevia päämääriä. Tämä koskee myös tasa-arvoista kansalaisuutta kansainvälistyvässä tieto- ja tuotantoverkostojen yhteiskunnassa.

Vision tiivistetyt ehdotukset kokoavat yhteen toimet, joita tähänastisessa keskustelussa on ehdotettu. Näiden toimien yhteinen nimittäjä on se, että vapaan sivistystyön kosketuspinta suomalaiseen yhteiskuntaan laajenee. Tarvitaan ydintarjonnan selkeyttämistä niin, että opittu voidaan tunnistaa. Tarvitaan tietoverkkojen käytön opastusta ja niiden avulla tapahtuvan opiskelun tukemista. Tarvitaan selkeitä tasa-arvoa parantavia askeleita. Eläkeikäisiin kohdistuva toiminta tarvitsee oman ohjelmansa, samoin Suomeen kiitettävästi virinneiden kehityshankkeiden opinnollinen tukeminen ja syrjäytymisen vastainen toiminta. Tarvitaan kansalaisyhteiskunnan varustamista opintopalveluilla. Tarvitaan työtä demokratia- ja moniarvoisuuskysymysten kanssa. Ja kansainvälistyvässä maailmassa kyky kansainvälistyä on myös tasa-arvokysymys.

Oleellista on kysyä, miten kansalais- ja työväenopistot tiivistävät visionsa vapaan sivistystyön suomalaisittain tärkeimpänä instituutiona. Selkeällä visiolla on kiire myös siksi, että ilman kuntien hallinnossa tapahtuvaa asennemuutosta vapaata sivistystyötä uhkaa sen kapasiteetin puolittuminen. Kansalais- ja työväenopistot tulee viedä rohkeasti kunnalliseen arvokeskusteluun ja kysyä, onko sivistys todellakin se, jonka annetaan säästöpaineissa kuolla. Kunnallinen sivistystoimi kokee näinä vuosina perusteellisia sisäisiä muutoksia. Oleellista on kysyä, miten vapaa sivistystyö omana tehtäväalanaan niistä selviää. Siihen keskusteluun tarvitaan kirkasta, tieto- ja osaamisyhteiskunnasta perusteensa hakevaa visiota.

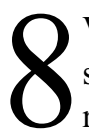

Vision toteuttaminen edellyttää nykyistä suurempaa rahoitusta ja eräin osin myös rahoitusperusteiden muutosta siksi, että erityisesti tasa-arvotavoite vaatii usein suurempaa panostusta. Rahoituksen kasvaminen tuntuu utopistiselta ja saattaa sitä kiristyvien julkisten budjettien valossa ollakin. Mutta pidän silti myös kasvavaa näkymää mahdollisena ja joka tapauksessa tavoittelemisen arvoisena.
Ennemmin tai myöhemmin myös julkisen rahan käytössä edetään juustohöylästä rakenteellisiin uudistuksiin. On aivan varmaa, että aikuiskasvatus on strategisen merkityksensä vuoksi uusjaon yksi voittaja. Vapaan sivistystyön tulee nykyisellä 20 prosentin osuudellaan pysyä aikuiskasvatuksen kasvuvauhdissa. Ja ainakin periaatteessa se voi nostaa omaa osuuttaan myös aikuiskasvatuksen rahoista.

Tällainen tulevaisuus edellyttää kuitenkin sitä, että päätöksentekijälle tarjotaan vankat perusteet. Alan ja sen järjestöjen haasteena on kehittää vision ehdotukset konkreettisiksi ohjelmiksi, joihin lasketaan myös ohjelman hinta. Ensivaiheessa ehdotetaan, että kärkeen nostettaisiin opitun tunnustaminen, ikääntyviin ja eläkeikään suunnattava toiminta ja kansanvalta. Mutta vastaavia ohjelmia tarvitaan myös muihin kehittämisen painopisteisiin.

Konkreettisten ohjelmien lisäksi tarvitaan rautainen sivistystyöntekijän ammattitaito ja sen jatkuva kehittäminen elinikäisen oppimisen periaatteiden mukaisesti. Siihen puolestaan VSOP ohjelma antaa puitteet. Niin valtion- kuin opetushallintokin näyttää nyt olevan harvanaisen valmis antamaan vapaalle sivistystyölle mahdollisuudet näyttää, mihin siitä on. Sama valmius tulisi saada myös kunnallishallintoon. Siltikin tulevaisuus riippuu ennen muuta siitä, ottaako ala itse vastuun VSOP -toiminnasta. Tähän tarvitaan sekä järjestöjen että oppilaitosten panosta. Sivistysväkenä en nyt hukkaisi aikaa vaan takoisin intoni ilosta kuumaa rautaa.

Seppo Niemelä on työskennellyt aiemmin Maaseudun Sivistysliiton toiminnanjohtajana sekä Vapaan Sivistystyön Yhteisjärjestön vt. toiminnanjohtajana. Hän on Kansanvalistusseuran hallintoneuvoston jäsen. Niemelä esitti visionsa KTOL:n tammiseminaarissa tänä vuonna. 